\title{
Erythrocyte factors concerned in the inhibition of ALA-D by lead
}

\author{
T SAKAI, S YANAGIHARA, AND K USHIO \\ From the Center of Occupational Medicine, Tokyo Labor Accident Hospital, Ota-Ku, Tokyo 143, Japan
}

\begin{abstract}
Erythrocyte factors are concerned in the inhibition of delta-aminolaevulinic acid dehydratase (ALA-D) by lead at 20 to $100 \mathrm{nM}$ concentrations. The activity of the factors is detected in $\mathrm{Hb}$ fractions from Sephadex G-200 gel filtration of erythrocyte supernatant. After gel filtration of erythrocyte supernatant from a lead worker, $50 \%$ of lead is found in ALA-D fractions, although the fractions recover from ALA-D inhibition. The recovered activity is reinhibited if the enzyme fraction is preincubated with $\mathrm{Hb}$ fraction obtained from the same chromatography. Similarly obtained enzyme from a normal subject is also inhibited when it is preincubated with normal $\mathrm{Hb}$ fraction and lead acetate at 20 to $100 \mathrm{nM}$ concentrations. The extent of the inhibition depends on the concentrations of $\mathrm{Hb}$ fraction and lead acetate preincubated. Reinhibition of lead worker enzyme with normal $\mathrm{Hb}$ fraction may be deleted not only by heating but also by zinc or DTT as well. $\mathrm{Hb}$ fraction heated at $60^{\circ} \mathrm{C}$ for $5 \mathrm{~min}$ is also able to induce the lead-inhibition of the activity in ALA-D fraction. Half life of the factors is $26 \mathrm{~min}$ at $60^{\circ} \mathrm{C}$ and $3 \mathrm{~min}$ at $80^{\circ} \mathrm{C}$.
\end{abstract}

Delta-aminolaevulinic acid dehydratase (ALA-D, EC 4.2.1.24) is an enzyme in the haem biosynthetic pathway that catalyses the dehydration and condensation of two moles of delta-aminolaevulinic acid into one mole of porphobilinogen. The enzyme, a homo-octamer with a molecular weight of 252000 , is activated by zinc ion at 0.1 and $0.02 \mathrm{mM}$ concentrations and inhibited by lead at 1 and $5 \mu \mathrm{M} .{ }^{1}$ The ALA-D activity of human blood is inhibited at blood lead concentrations between 200 and $1000 \mu \mathrm{g}$ (1.0 and $4.8 \mu$ moles)/ $/$ blood, and serves as an indicator of lead exposure..$^{-5}$

The inhibitory action of lead at low concentrations on ALA-D activity has been a subject of recent interest because of its characteristic properties. The depressed activity by lead exposure can be restored by the following agents or treatments in vitro: gel filtration, ammonium sulphate precipitation, ${ }^{6}$ or heating of haemolysate ${ }^{6-9}$ or the addition of $\mathrm{SH}$ compounds (such as dithiothreitol (DTT), reduced glutathione $(\mathrm{GSH}))^{10^{-12}}$ or zinc ion $^{13^{-16}}$ to the reaction mixture. Zinc ion introduced subcutaneously to an animal also reverses the lead-inhibition of ALA-D activity in vivo. ${ }^{17}$

Although several hypotheses have been raised on

Received 5 August 1980

Accepted 18 August 1980 the mechanism of ALA-D inhibition by lead, ${ }^{6} 9121318$ it has not yet been established. We have reported that the preincubation of lead salt with haemolysate intensifies ALA-D inhibition. ${ }^{19}$ Here we describe the involvement of protein factors in ALA-D inhibition by lead at 20 to $100 \mathrm{nM}$ concentrations, which are 50 -fold lower than the inhibition concentration of highly purified enzyme described previously. ${ }^{1}$

\section{Materials and methods}

Heparinised venous blood was obtained from workers occupationally exposed to lead and from normal subjects without any history of lead exposure. All procedures for the preparation of ALA-D fractions and $\mathrm{Hb}$ fractions were carried out at $4^{\circ} \mathrm{C}$. Packed erythrocytes were washed three times in cooled saline $(0.9 \%)$ and adjusted to the original haematocrit value with $0.025 \mathrm{M}$ phosphate buffer pH 7.2. Erythrocytes were completely lysed by sonicating. The lysate was centrifuged at $24000 \mathrm{~g}$ for $60 \mathrm{~min}$. The obtained erythrocyte supernatant was applied to Sephadex G-25 or G-200 columns $(2.6 \times 90 \mathrm{~cm})$ that had been equilibrated with 0.025 $\mathrm{M}$ phosphate buffer $\mathrm{pH} 7 \cdot 2$, and eluted with the same buffer. The ALA-D and $\mathrm{Hb}$ fractions thus obtained were pooled and used for the following experiments. ALA-D activity was determined by the method by 
Ushio et $\mathrm{l}^{7}$ with the exception that ALA-D fractions pooled were diluted 2 - to 5 -fold with the elution buffer and used as the enzyme solution in the present experiments. The standard mixture contained $0.5 \mathrm{ml}$ of enzyme solution, $0.5 \mathrm{ml}$ of $0.2 \mathrm{M}$ phosphate buffer pH $7.0,0.5 \mathrm{ml}$ of $20 \mathrm{mM}$ ALA (deltaaminolaevulinic acid) solution, and $1 \mathrm{ml}$ of distilled water. To inhibit the recovered activity of ALA-D through Sephadex G-200 gel filtration, the pooled $\mathrm{Hb}$ fraction and lead acetate, or both, were added to the mixture without ALA solution and preincubated at $4{ }^{\circ} \mathrm{C}$ for 20 hours. For the activation of ALA-D, zinc chloride or DTT was added to the mixture instead of distilled water. Another activation procedure was the heat treatment of enzyme solution in the presence of phosphate buffer at $60^{\circ} \mathrm{C}$ for $5 \mathrm{~min}$ as reported by Ushio et al. ${ }^{7}$ After the activation procedures, ALA-solution was added, and the reaction was carried out at $37^{\circ} \mathrm{C}$ for $60 \mathrm{~min}$. The reaction was stopped by adding $1 \mathrm{ml}$ of $10 \%$ trichloroacetic acid solution containing $0.1 \mathrm{M}$ $\mathrm{HgCl}_{2}$. The amount of formed porphobilinogen was measured at $555 \mathrm{~nm}$ by adding $1 \mathrm{ml}$ of Ehrlich's reagent to $1 \mathrm{ml}$ of supernatant.

The protein concentration was measured by the absorbance at $280 \mathrm{~nm}$, and the $\mathrm{Hb}$ concentration was determined using a haemoglobin counter (TOA Medical Electronic Co, Ltd, Japan), which directly measures $\mathrm{Hb}$ concentration spectrophotometrically as cyanmethaemoglobin. The lead concentration in the pooled fractions was determined as reported by Ushio et al. ${ }^{7}$

\section{Results}

Figure 1 shows the pH optimum and heat activa. tion of ALA-D prepared from Sephadex G-25 (a) and G-200 (b) gel filtrations. Results with the enzyme from Sephadex G-25 (a) is similar to those obtained with whole blood ${ }^{7}$ : the $\mathrm{pH}$ optimum of ALA-D from a lead worker is slightly lower than that from a normal subject. After heat treatment, the depressed enzyme activity in the lead workers is appreciably restored in the high $\mathrm{pH}$ range. These findings indicate that erythrocyte components of low molecular weight have no effect on the inhibition of ALA-D by lead and on its restoration by heat treatment. On the contrary, the inhibition due to lead apparently disappears after Sephadex G-200 gel filtration (b). The effect of heat treatment on the activity of the enzyme from lead workers, however, is different from that of the normal enzyme. The activity of the normal enzyme is decreased by heat treatment in the high $\mathrm{pH}$ range, while that from lead workers is rather stable. These results indicate that the effect of lead on the enzyme remains even after
Sephadex G-200 gel filtration, and also suggests that certain components with a high molecular weight are concerned in the disappearance of ALA-D inhibition after gel filtration.

Figures 2(a) and 3(a) show Sephadex G-200 chromatography of erythrocyte supernatant from a lead worker and from a normal subject, respectively. Lead concentrations were determined in four fractions (I-IV) pooled as shown in figs 2(a) and 3(a)

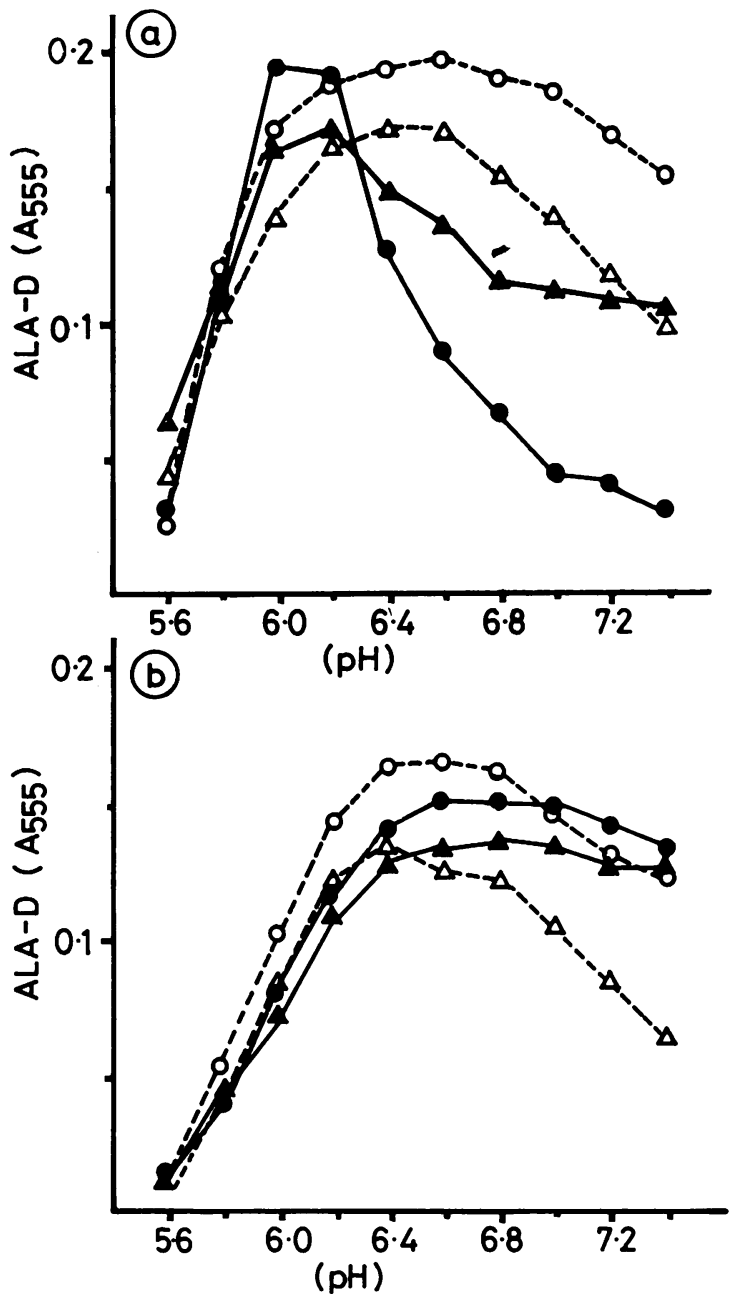

Fig 1 pH optimum and heat activation of $A L A-D$ obtained by Sephadex G-25 (a) or G-200 (b) gel filtration of erythrocyte supernatant. Erythrocyte supernatant from a lead worker $(64 \mu \mathrm{g} / 100 \mathrm{~g}$, $-1-,-\bigcirc--)$ or from a normal subject (10 $\mu \mathrm{g} / 100 \mathrm{~g},-\Delta-,-\triangle--)$ was gel filtrated. Pooled ALA-D fraction was used as enzyme solution and heated at $60^{\circ} \mathrm{C}$ for 5 min $(--\bigcirc--,--\triangle--)$. Control (- - - - - - was not heated. 

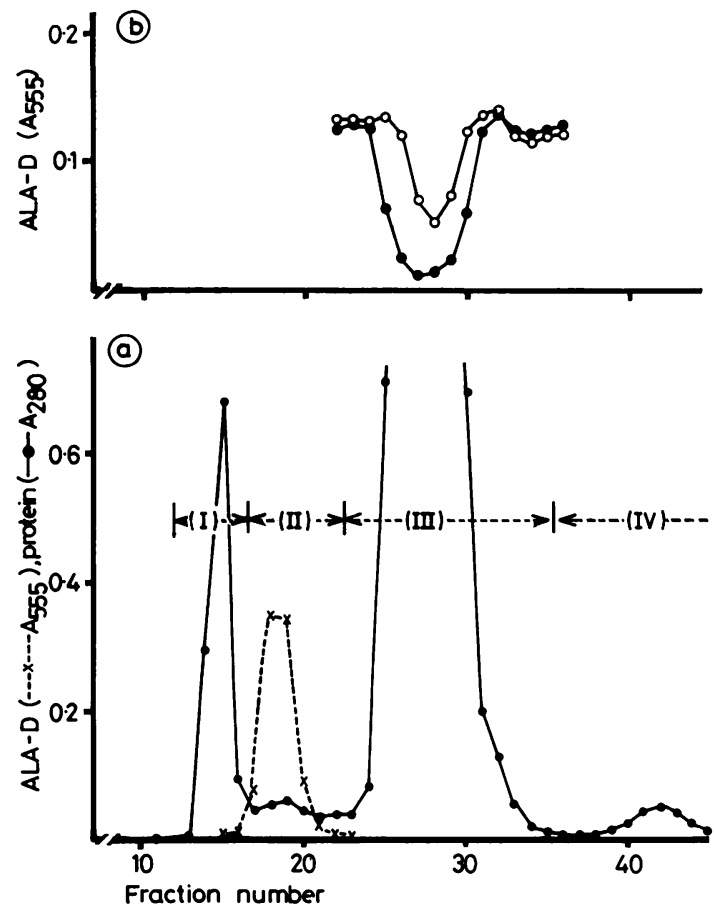

Fig 2 Sephadex G-200 gel filtration of erythrocyte supernatant from a lead worker $(a)$, and the factors concerned in ALA-D inhibition by lead (b). (a): Ten millilitre of whole blood from a lead worker $(51 \mu \mathrm{g} / 100 \mathrm{~g})$ was used to prepare erythrocyte supernatant. (b): Pooled ALA-D fraction was preincubated with each fraction of 22 to 36 at $4^{\circ} \mathrm{C}$ for $20 \mathrm{hr}$. After preincubation, the mixture was further heated at $60^{\circ} \mathrm{C}$ for $5 \min (\longrightarrow-\mathrm{O}-$. Control (- - $\longrightarrow$ was not heated.

(table 1). Fifty per cent of the lead in erythrocyte supernanant from a lead worker is bound to proteins in ALA-D fractions (II). The lead found in ALA-D fractions may be responsible for the different effect of heating on the enzyme activity as seen in fig 1(b).

To detect the factors possibly involved in ALA-D inhibition by lead, we assayed the inhibitory action of some fractions obtained by Sephadex G-200 gel filtration (figs 2(b) and 3(b, c)). The enzyme from a lead worker with a blood lead concentration of $51 \mu \mathrm{g} / 100 \mathrm{~g}$ is extremely inhibited in the presence of $\mathrm{Hb}$ fractions, and the inhibition is partially restored by heat treatment (fig 2(b)). By contrast, in a normal subject, ALA-D inhibition with $\mathrm{Hb}$ fractions is less than that in a lead worker. The slight inhibition is probably the effect of $\mathrm{Hb}$ itself ${ }^{20}$ (fig 3(b)). The normal enzyme is appreciably inhibited by lead acetate at a concentration of $100 \mathrm{nM}$ in the presence of $\mathrm{Hb}$

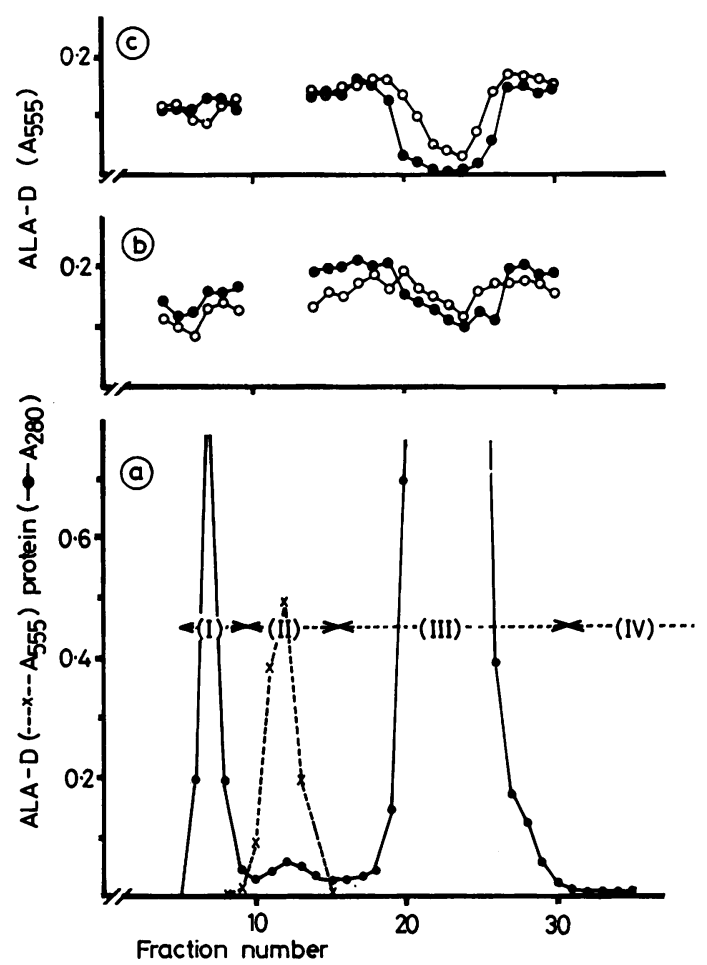

Fig 3 Sephadex G-200 gel filtration of erythrocyte sypernatant from a normal subject $(a)$, and the factors concerned in ALA-D inhibition by lead ( $b$ and $c$ ). ( $a)$ : Ten millilitre of whole blood from a normal subject $(9$ $\mu \mathrm{g} / 100 \mathrm{~g}$ ) was used to prepare erythrocyte supernatant. (b) and (c): Pooled ALA-D fraction was preincubated with each fraction of 4 to 9 and 14 to 30 in presence of lead acetate $(100 \mathrm{nM})(\mathrm{c})$ or in the absence $(b)$. After preincubation, mixture was further heated at $60^{\circ} \mathrm{C}$ for 5 $\min (\longrightarrow \mathrm{O}-$ ). Control (- - - was not heated.

fractions, and the inhibition is also partially restored by heat treatment (fig 3(c)). These findings indicate that in $\mathrm{Hb}$ fractions factors induce or intensify ALA-D inhibition by lead at low concentrations. In view of the fact that $\mathrm{Hb}$ further purified by ion

Table 1 Distribution of lead in the erythrocyte supernatant

\begin{tabular}{lrrrrr}
\hline $\begin{array}{l}\text { Lead in erythrocyte } \\
\text { supernatant } \\
(n g / 10 \mathrm{ml})\end{array}$ & \multicolumn{5}{l}{ Lead in pooled fractions $(\mathrm{ng})$} \\
\cline { 2 - 6 } & \multicolumn{1}{c}{$I$} & $I I$ & $I I I$ & $I V$ & Total \\
\hline $900^{\mathrm{a}}$ & 96 & 330 & 330 & 96 & 862 \\
$4900^{\mathrm{b}}$ & 374 & 2499 & 1661 & 434 & 4968 \\
\hline
\end{tabular}

Erythrocyte supernatant from a lead worker $(51 \mu \mathrm{g} / 100 \mathrm{~g})^{\mathrm{b}}$ and from a normal subject $(9 \mu \mathrm{g} / 100 \mathrm{~g})^{\mathrm{a}}$ was gel filtrated on a Sephadex G-200 column. Lead contents were determined in four pooled fractions (I-IV as shown in figs 2 and 3 ). 


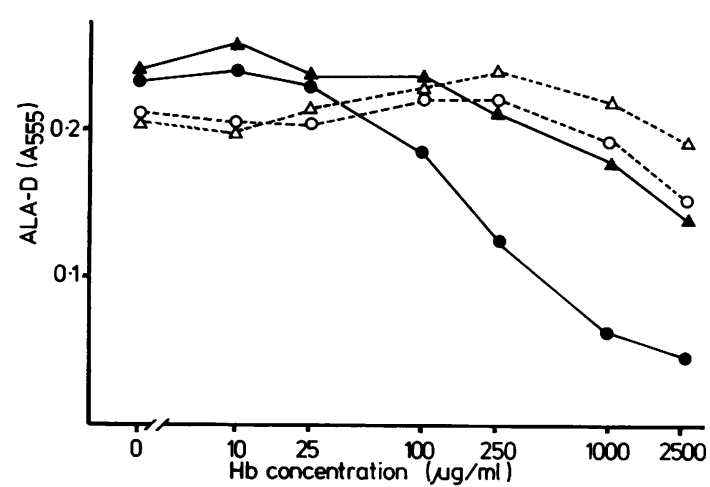

Fig 4 Effect of increasing amount of pooled $\mathrm{Hb}$ fraction on $A L A-D$ inhibition and on its heat-restoration. Pooled $A L A-D$ fraction and $\mathrm{Hb}$ fraction were prepared from normal erythrocytes. ALA-D fraction was preincubated with increasing amount of $\mathrm{Hb}$ fraction in presence (-_- - - -

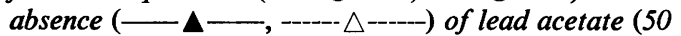
$n M)$. After preincubation, enzyme was heated (-- $\mathrm{-}(--)$ -

exchange chromatography has a similar effect on ALA-D inhibition by lead, $\mathrm{Hb}$ itself seems to have such an effect (data not shown).

Figure 4 shows the effect of increasing the amount of proteins in the pooled $\mathrm{Hb}$ fraction on the inhibition of ALA-D by lead acetate and also on its restoration by heat treatment. Lead acetate at a concentration of $50 \mathrm{nM}$ causes little inhibition (under $3 \%$ ) in the absence of pooled $\mathrm{Hb}$ fraction. As the amount of $\mathrm{Hb}$ increases (100 to $2500 \mu \mathrm{g} / \mathrm{ml})$, ALA-D inhibition by lead acetate progresses appreciably. In the absence of lead these concentrations of $\mathrm{Hb}$ produce slight inhibition, an effect due solely to $\mathrm{Hb}^{20}$ The inhibition of ALA-D activity by lead, which is intensified by the $\mathrm{Hb}$ fraction, may be restored by heat treatment. Under our assay conditions, a concentration of $2500 \mu \mathrm{g} / \mathrm{ml}$ is derived from blood with $12.5 \mathrm{gHb} / \mathrm{dl}$.

Figure 5 shows the inhibition of ALA-D by increasing amounts of lead acetate in the presence of pooled $\mathrm{Hb}$ fraction, and its restoration by three agents or manoeuvres. In the presence of the $\mathrm{Hb}$ fraction 80 and $100 \mathrm{nM}$ of lead acetate causes more than $90 \%$ inhibition, and $10 \mathrm{mM}$ DTT or $100 \mu \mathrm{M}$ zinc can restore the activity completely; restoration is incomplete with heating. In the absence of the $\mathrm{Hb}$ fraction lead acetate at concentration between 0 and $100 \mathrm{nM}$ does not inhibit the activity of the enzyme (data not shown). Based on these observations, it is clear that factors in the $\mathrm{Hb}$ fractions are concerned

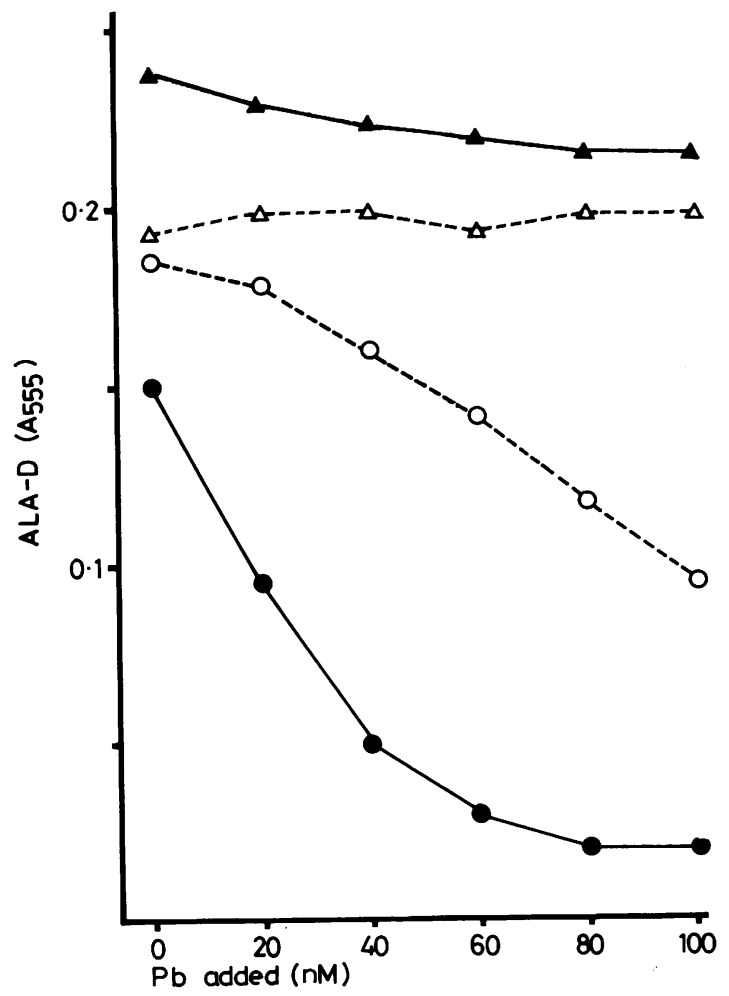

Fig $5 A L A-D$ inhibition by increasing amount of lead acetate, and its restoration by each of three agents. Pooled $A L A-D$ fraction and $\mathrm{Hb}$ fraction were prepared from normal erythrocytes. Pooled ALA-D fraction was preincubated with $\mathrm{Hb}$ fraction and varying amount of lead acetate (0-100 $n M)$. After preincubation, the inhibited activity (____ $)$ was restored by heating (-O--), $100 \mu \mathrm{M}$ zinc (-- $\triangle--)$, or $10 \mathrm{mM}$ DTT (- $\triangle \longrightarrow)$.

in the inhibition of ALA-D by lead at low concentrations.

Table 2 shows the effect of various treatments on

Table 2 Effect of various treatments on the activity of lead-bound $A L A-D$ in the presence or absence of pooled $\mathrm{Hb}$ fraction

\begin{tabular}{lll}
\hline Treatments & \multicolumn{2}{l}{$A L A-D$ activity $\left(A_{555}\right)$} \\
\cline { 2 - 3 } & $-H b$ fr & $+H b$ fr \\
\hline Control & 0.423 & 0.039 \\
Heating & 0.390 & 0.181 \\
Zinc $(20 \mu \mathrm{M})$ & 0.320 & 0.120 \\
Zinc $(100 \mu \mathrm{M})$ & 0.081 & 0.296 \\
DTT $(10 \mathrm{mM})$ & 0.447 & 0.351 \\
\hline
\end{tabular}

Enzyme from Sephadex G-200 gel filtration of erythrocyte supernatant of a lead worker $(57 \mu \mathrm{g} / 100 \mathrm{~g})$ was preincubated in presence or absence of $\mathrm{Hb}$ fraction from Sephadex G-200 gel filtration of normal erythrocyte supernatant $(10 \mu \mathrm{g} / 100 \mathrm{~g})$. 


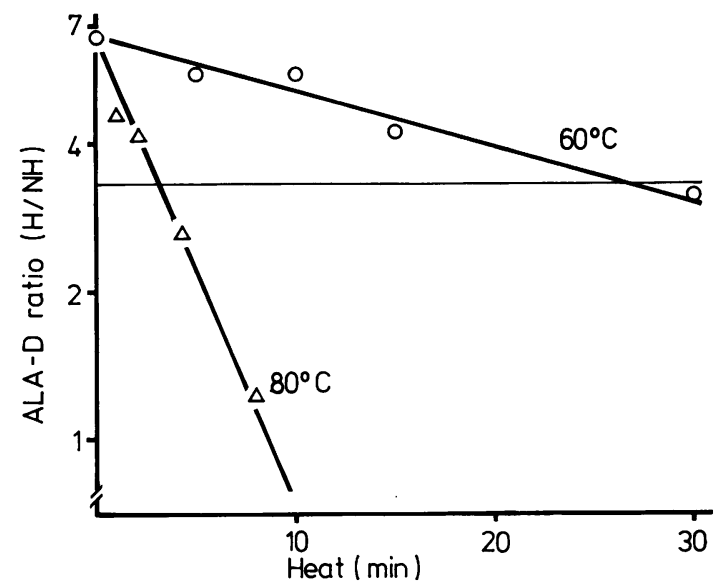

Fig 6 Heat stability of the factors. Pooled $\mathrm{Hb}$ fraction from normal erythrocytes was heated at $60^{\circ} \mathrm{C}(\mathrm{O})$ or $80^{\circ} \mathrm{C}(\triangle)$ for 0-30 min. Heated $\mathrm{Hb}$ fraction was then preincubated with enzyme fraction from normal erythrocytes and lead acetate (50 nM). Enzyme activity was determined with $(H)$ or without $(N H)$ 2nd heat treatment $\left(60^{\circ} \mathrm{C}, 5 \mathrm{~min}\right)$. Ability of factors in $\mathrm{Hb}$ fraction was expressed as ratio of $A L A-D$ activity $(\mathrm{H} / \mathrm{NH})$.

the activity of lead-bound enzyme from a lead worker. In the absence of pooled $\mathrm{Hb}$ fraction the activity of the lead-bound enzyme, which has been reversed by gel filtration, is not more activated by heating, zinc, or by DTT. The reversed lead-bound enzyme is reinhibited if it is preincubated with the $\mathrm{Hb}$ fraction from a normal subject. The reinhibition is partially removed again by heating, or by the addition of zinc or DTT. The optimum concentration of zinc is $20 \mu \mathrm{M}$ in the absence of the $\mathrm{Hb}$ fraction, and $100 \mu \mathrm{M}$ in its presence. An optimum concentration of zinc is dependent on the concentration of $\mathrm{Hb}$ (data not shown).

Figure 6 indicates the heat stability of the factors found in the $\mathrm{Hb}$ fractions. The ability of the factors to restore the ALA-D inhibition is decreased by preheating at $60^{\circ} \mathrm{C}$ or $80^{\circ} \mathrm{C}$. The half life is about 26 min at $60^{\circ} \mathrm{C}$ and $3 \mathrm{~min}$ at $80^{\circ} \mathrm{C}$. The ability is not influenced by preheating for $5 \mathrm{~min}$ at $60^{\circ} \mathrm{C}$. This indicates that the restoration of depressed activity by heat treatment is not due to the inactivation of the inhibiting factors.

\section{Discussion}

In the present study we have shown the involvement of erythrocyte factors in the inhibition of ALA-D at low lead concentrations. The ability of these factors to intensify the inhibition of ALA-D by lead was detected in the $\mathrm{Hb}$ fractions obtained by Sephadex
G-200 gel filtration of erythrocyte supernatant.

Highly purified ALA-D is inhibited by lead at 1 and $5 \mu \mathrm{M}$ concentrations $(\mathrm{Ki}=1.7 \mu \mathrm{M}),{ }^{1}$ and the crude enzyme is also inhibited at concentrations exceedings $1 \mu \mathrm{M} .{ }^{16}$ Both are final concentrations in the assay mixture. Under our routine conditions, lead at toxic concentrations $(50-100 \mu \mathrm{g} / 100 \mathrm{~g}$ of blood) are finally between 50 and $100 \mathrm{nM}$ in the mixture, because the whole blood is diluted 50 -fold. These concentrations are 10 to 50 -fold lower than those in the purified or crude enzyme in vitro.

We have previously suggested that there are two types of ALA-D inhibition in vitro, using whole blood as the enzyme source. ${ }^{19}$ If the enzyme is preincubated with lead at 50-500 nM concentrations, pronounced inhibition can be induced and then reversed by heating. By contrast, the inhibition by lead acetate at concentrations exceeding $1 \mu \mathrm{M}$ cannot be restored by heating. The difference between the two types of ALA-D inhibition by lead at low or high concentrations suggests the presence of two different binding sites for lead ions on the enzyme molecules. Lead ion at the low concentrations probably binds to certain site on the enzyme molecules during preincubation, and results in the inhibition that can be restored by heating. This site should have a high affinity for lead ions. At the high concentrations, lead would bind to sites other than the high affinity site, and this results in the type of inhibition that cannot be restored by heating. Thus we postulate two types of site on the enzyme molecules. The enzyme has many SH-groups ${ }^{21}$ that seem to have individual sensitivity to lead.

After Sephadex G-200 gel filtration of the erythrocyte supernatant from lead workers, $50 \%$ of the lead was actually found in the ALA-D fraction. The activity of the ALA-D fraction was inhibited if preincubated with the pooled $\mathrm{Hb}$ fraction from a normal subject. Enzyme obtained in a similar fashion from normal erythrocyte supernatant was also considerably inhibited if it had been preincubated with lead acetate $(100 \mathrm{nM})$ in the presence of the $\mathrm{Hb}$ fraction. This inhibition could be partially reversed by heat treatment. In the absence of the $\mathrm{Hb}$ fraction enzyme from both a lead worker and a normal subject was not inhibited even if preincubated. Thus factors found in the $\mathrm{Hb}$ fraction may mediate between the lead ion and the high affinity site on the molecules, resulting in the inhibition of ALA-D by low concentrations of lead.

The inhibition of ALA-D by low concentrations of lead is non-competitive, ${ }^{7}$ while the inhibition of the highly purified enzyme by lead ion at high concentrations is complex in type. ${ }^{1}$ The type of inhibition mediated by the factors in vitro seems to be similar to the former, and to be non-competitive because of 
the inhibition by lead at low concentrations and of the restoration of activity by heat. We may speculate on the non-competitive action of lead (bound to the high affinity site) at low concentrations as follows:

$$
\begin{aligned}
& \mathrm{S}+\mathrm{E}-\mathrm{Pb} \rightarrow \mathrm{E}-\mathrm{Pb}-\mathrm{S} \rightarrow \mathrm{E}-\mathrm{Pb}+\mathrm{P} \\
& \mathrm{S}+\mathrm{E}-\mathrm{Pb}-\mathrm{F} \rightarrow \mathrm{E}-\mathrm{Pb}-\mathrm{F}-\mathrm{S}
\end{aligned}
$$

Although lead bound to the high affinity site(s) does not inhibit enzyme activity without the factor $(F)$, the factor might affect the conformation of enzyme-lead complex (E-Pb), resulting in the failure of dissociation of the intermediate complex (E-Pb-F-S) into the product $(\mathrm{P}){ }^{22}$

The inhibition by lead bound to the high affinity site that was mediated by the factors was restored by heating, zinc, or DTT. The restoration of activity by heat may be due to the following, reversible process: 19

$$
\mathrm{E}-\mathrm{Pb}-\mathrm{F} \leftrightarrow \mathrm{E}-\mathrm{Pb}+\mathrm{F}
$$

where the forward reaction is promoted by heat treatment at $60^{\circ} \mathrm{C}$ for $5 \mathrm{~min}$, and the backward reaction by preincubation at $4{ }^{\circ} \mathrm{C}$ for $20 \mathrm{hr}$ or $37^{\circ} \mathrm{C}$ for $3 \mathrm{~h}$. The factors mentioned above may be the same as those suggested by Vergnano et al,$^{6}$ although ours are not inactivated by heating at $60^{\circ} \mathrm{C}$ for 5 min, and their action is reversible. ${ }^{19}$ The nature of the factors remains to be resolved.

The action of zinc or DTT in restoring the activity of the enzyme seems to differ from that of heating. Zinc is most effective and may be essential for the activity of the enzyme since zinc ion restores the inhibition by both low and high lead concentrations. Relatively high concentrations of zinc have an antagonistic effect on the inhibition of ALA-D by lead in vitro. ${ }^{13}$ Zinc added at a high concentration could replace lead on the enzyme molecule, although lead has a greater affinity for binding with SH-group than zinc. ${ }^{23}$ DTT has dual effects on the activity through SH-groups on the molecules; ${ }^{24}$ it not only restores the activity of the enzyme when inhibited by lead but also when inactivated by the oxidation of SH-groups. While the inhibition by low lead concentrations was reversed by DTT, increasing amounts of lead reduced the degree to which DTT restored activity. This suggests that DTT only restores the inhibition due to lead bound to high affinity sites. The recent finding that the addition of zinc to the apoenzyme completely restores the activity if the essential SH-groups are first reduced with SH-reagents is of considerable interest. ${ }^{21}$ Further study is necessary to clarify the mode of action of zinc, DTT, or the factors in the restoration of leadinhibited activity or all.

\section{References}

${ }^{1}$ Anderson PM, Desnick RJ. Purification and properties of $\delta$-aminolevulinate dehydrase from human erythrocytes.
J Biol Chem 1979;254:6924-30.

2 Bonsignore D, Calissano P, Cartasegna C. A simple method for determining delta-aminolevulinic-dehydratase in the blood. Behavior of the enzyme in lead poisoning. Med Lav 1965;56:199-205.

${ }^{3}$ de Bruin A, Hoolboom H. Early signs of lead-exposure. A comparative study of laboratory tests. $\mathrm{Br} \mathrm{J}$ Ind Med 1967;24:203-12.

4 Nakao K, Wada O, Yano Y. $\delta$-aminolevulinic acid dehydratase activity in erythrocytes for the evaluation of lead poisoning. Clin Chim Acta 1968;19:319-25.

${ }^{5}$ Hernberg S, Nikkanen J, Mellin G, Lilus H. $\delta$-aminolevulinic acid dehydrase as a measure of lead exposure. Arch Environ Health 1970;21:140-5.

6 Vergnano C, Cartasegna C, Ardoino V. Mechanisms of erythrocytic $\delta$-aminolevulinic acid (ALA) dehydratase inhibition in human and experimental lead-poisoning. Med Lav 1969;60:505-16.

7 Ushio K, Sakai T, Yanagihara S, Watanabe H. Properties of ALA-D ( $\delta$-aminolevulinic acid dehydratase) and the evaluation of lead exposure using heat activation. Jap J Ind Health 1975;17:475-82.

${ }^{8}$ Tomokuni K, Kawanishi T. Relationship between activation of delta-aminolevulinic acid dehydratase by heating and blood lead level. Arch Toxicol 1975;34: 253-8.

${ }^{9}$ Chiba M. Activity of erythrocyte $\delta$-aminolaevulinic acid dehydrase and its change by heat treatment as indices of lead exposure. $\mathrm{Br}$ J Ind Med 1976;33:36-42.

${ }^{10}$ Haas Th, Mache W, Schaller K-H, Mache K, Klavis G, Stumpf R. The determination of delta-aminolevulinic acid dehydratase activity and its diagnostic value. Internationales Archiv fur Arbeitzmedizin 1972;30:87-104.

${ }^{11}$ Granick JL, Sassa S, Granick S, Levere RD, Kappas A. Studies in lead poisoning. II Correlation between the ratio of activated $\delta$-aminolevulinic acid dehydratase of whole blood and the blood lead level. Biochem Med $1973 ; 8: 149-59$.

${ }^{12}$ Hapke H-J, Prigge E. Interactions of lead and glutathione with delta-aminolevulinic acid dehydratase. Arch Toxicol 1973;31:153-61.

${ }^{13}$ Finelli VN, Klauder DS, Karaffa MA, Petering HG. Interaction of zinc and lead on $\delta$-aminolevulinate dehydratase. Biochem Biophys Res Commun 1975;65: 303-11.

${ }^{14}$ Border EA, Cantrell AC, Kilroe-Smith TA. The in-vitro effect of zinc on the inhibition of human $\delta$-aminolaevulinic acid dehydratase by lead. $\mathrm{Br} J$ Ind Med 1976;33:85-7.

${ }^{15}$ Cantrell AC, Kilroe-Smith TA, Simoes MM, Border EA. The effect of zinc and $\mathrm{pH}$ on the behaviour of $\delta$-aminolaevulinic acid dehydratase activity in baboons exposed to lead. Br J Ind Med 1977;34:110-3.

${ }^{16}$ Sakai T, Yanagihara S, Ushio K. Effect of metal ions on ALA-D activity in vitro and evaluation of lead-burden by zinc activation of ALA-D. Journal of Japan Accident Medical Association 1979;27:30-8.

${ }^{17}$ Haeger-Aronsen B, Schutz A. Antagonistic effect in vivo of zinc on inhibition of $\delta$-aminolevulinic acid dehydratase by lead. Arch Environ Health 1976;31:215-20.

${ }_{18}$ Nikkanen J, Hernberg S, Tola S. Modifications of the $\sigma$-aminolevulinic acid dehydratase test and their significance for assessing different intensities of lead exposure. Work Environ Health 1972;9:46-52.

${ }^{19}$ Sakai T, Yanagihara S, Ushio K. Effect of preincubation on ALA-D inhibition by added lead. Journal of Japan Accident Medical Association 1980;28:56-61.

${ }^{20}$ Calissano P, Bonsignore D, Cartasegna C. Control of haem synthesis by feedback inhibition on human-erythrocyte $\delta$-aminolaevulate dehydratase. Biochem $J$ 1966;101: 
$550-2$.

${ }^{21}$ Bevan DR, Bodlaender P, Schemin D. Mechanism of porphobilinogen synthase. Requirement of $\mathrm{Zn}^{2+}$ for enzyme activity. $J$ Biol Chem 1980;255:2030-5.

22 Barman TE. Inhibitors. In: Enzyme handbook. Vol I. Berlin: Springer-Verlag, 1969:10-2.

${ }^{23}$ Thompson J, Jones DD, Beasley WH. The effect of metal ions on the activity of $\delta$-aminolaevulinic acid dehydratase. Br J Ind Med 1977;34:32-6.

${ }^{24}$ Sakai T, Yanagihara H, Ushio K. Restoration of leadinhibited 5-aminolevulinate dehydratase activity in whole blood by heat, zinc ion, and (or) dithiothreitol. Clin Chem 1980;26:625-8. 